BOŻENA KANCLERZ

Uniwersytet im. Adama Mickiewicza

w Poznaniu

\title{
ORIENTACJA \\ NA UCZESTNICTWO WSPÓŁCZESNEJ MŁODZIEŻY - STAN I POTRZEBY EDUKACYJNE
}

ABSTRACT. Kanclerz Bożena, Orientacja na uczestnictwo wspótczesnej młodzieży - stan i potrzeby edukacyjne [Orientation for the Participation of Today's Youth - Present State and Educational Needs]. Studia Edukacyjne nr 42, 2016, Poznań 2016, pp. 177-189. Adam Mickiewicz University Press. ISSN 12336688. DOI: $10.14746 /$ se.2016.42.10

The main goal of this article is to discuss the social involvement of young people and the associated social trust. Article refers to the theoretical analysis and the results of their research. In the first part author analyzes the social participation and confidence in the institutions of social life. Results of the study are compared with other results. On the one hand, young people declare their willingness to help others. On the other hand, often insufficiently actively participate in social life and do not trust the institution. The second part of the article author draws attention to the formal and informal education as a tool for development of social skills.

Key words: youth, orientation for the participation, social trust, social capital

\section{Młodzież w świecie współczesnym}

W świecie, gdzie indywidualizm oraz nastawienie na samorealizację w powszechnym przekonaniu stały się podstawą funkcjonowania młodych ludzi, których sprawy i życie kształtują się w ramach ",hiperprogramu tworzonego przez konsumpcję, mass media i popkulturę ${ }^{1 \prime}$, niezwykle interesujące wydaje się podejście młodzieży do kategorii uczestnictwa $w$ życiu społecznym, będącej odmienną i przeciwstawną $\mathrm{w}$ swych założeniach

1 Z. Melosik, Kultura popularna, pedagogika i młodziez, [w:] Wychowawcze i społeczno-kulturowe kompetencje współczesnych nauczycieli, red. J. Pyżalski, Łódź 2015, s. 34. 
perspektywą względem indywidualizmu, rozumianego jako postawy charakteryzującej jednostki, których tożsamość zasadza się na ostrym rozróżnieniu , ,ja" - „inni"2. Orientacja na uczestnictwo jest kategorią teoretyczną, związaną z rozumieniem rzeczywistości społecznej $\mathrm{w}$ kategoriach systemów, grup społecznych, jak też indywidualnych jednostek, którym można pomagać. Uczestnictwo łączy się $\mathrm{z}$ wrażliwością na potrzeby drugiego człowieka, ale także wyraża $\mathrm{w}$ chęci jednostki do zaangażowania się $\mathrm{w}$ realizację idei społecznie ważnych, które mogą przyczynić się do zmian w strukturze społecznej czy indywidualnych losach jednostek ${ }^{3}$. Jak podkreśla A. Cybal-Michalska, uczestniczenie jest działaniem społecznym i pobudza solidarność w przestrzeni, a od stopnia aktywnego, efektywnego i odpowiedzialnego uczestnictwa oraz współdziałania społecznego na szczeblu lokalnym, krajowym, międzynarodowym i ponadnarodowym zależy zakres innowacyjnego działania $\mathrm{w}$ wymiarze globalnym ${ }^{4}$. Dynamika przeobrażeń, których doświadczamy każdego dnia nie pozostaje bez wpływu na kształtowanie się indywidualnych postaw życiowych i celów, jakie chcą realizować młodzi ludzie będący w trudnym okresie wchodzenia w dorosłe życie. Dorastanie to nie tylko intensywne kształtowanie swojej tożsamości w wymiarze indywidualnym, ale także czas odpowiedzi na pytanie: Kim jestem $\mathrm{i}$ jakie jest moje miejsce $\mathrm{w}$ zmieniającym się świecie? Młode pokolenie, jak zwraca uwagę K. Mannheim, jest nie tylko odbiorcą, ale przede wszystkim podmiotem prospektywnych przemian. Młodzież jest czynnikiem dynamizującym strukturę społeczną, wnosząc do niej wartości innowacyjne oraz wywierając wpływ na przemiany społeczeństwa ${ }^{5}$. Rozważaniom autora towarzyszy także przekonanie, że $\mathrm{w}$ młodzieży tkwi potencjał gotów do zaczęcia wszystkiego od nowa ${ }^{6}$. To właśnie dlatego perspektywa młodzieży, jej sposób funkcjonowania, myślenia o społeczeństwie jest niezwykle interesująca, bowiem młodzież jako grupa społeczna ma wpływ na to co dzieje się ,'tu i teraz", ale także w znacznym stopniu decyduje o przyszłości. Młodzież, zarówno nie posiadająca jeszcze pełni praw obywatelskich, jak i młodzi do-

2 J. Reykowski, K. Skarżyńska, M. Ziółkowski (red.), Orientacje społeczne jako element mentalności, Poznań 1990, s. 17, cyt. za: P. Peret-Drążewska, Wspótczesna młodzież postrzegana z perspektywy rówieśników, Poznań 2014, s. 89.

3 B. Kanclerz, Orientacje życiowe młodzieży akademickiej, Poznań 2015, s. 212-213.

4 A. Cybal-Michalska, Tożsamość młodzieży w perspektywie globalnego świata, Poznań 2006, s. 73.

${ }^{5}$ K. Mannheim, Problem pokoleń, Colloquia Communia, 1992-1993, 1-12, s. 57-68, cyt. za: Młodzi 2011, red. M. Boni, K. Szafraniec, Warszawa 2011, s. 21.

${ }^{6} \mathrm{~K}$. Mannheim, Problem młodzieży w nowoczesnym społeczeństwie, [w:] Młodzież jako problem i jako wyzwanie ponowoczesności. Z prac Sekcji Socjologii Edukacji i Młodzieży PTS 2011 - tom II, red. K. Szafraniec, Kraków 2011, s. 15. 
rośli, to $\mathrm{w}$ odniesieniach konceptualno-teoretycznych pedagogiki emancypacyjnej czy antyautorytarnej aktywne społecznie podmioty, jako społeczni aktorzy zdolni do działania na własny rachunek oraz upoważnieni do tego by zabierać głos w sprawach pozaosobistych - społecznych i życia społecznego, w którym biorą udział7. Żyjąc w czasach powszechnej dostępności zarówno do informacji jak i dóbr, korzystając z wolności i swobód obywatelskich, młodzi muszą na nowo $\mathrm{w}$ stosunku do pokoleń poprzednich zdefiniować swoje cele życiowe i sposób ich realizacji ${ }^{8}$. Tak zaprezentowane podejście czyni młodzież - ich świat przeżywany, opinie, poglądy oraz wybory życiowe niezwykle ciekawym i ciągle aktualnym problemem, zarówno w sferze teoretycznych rozważań, jak i eksploracji badawczych.

\section{Orientacja na uczestnictwo - perspektywa teoretyczna}

Aktywność w życiu społecznym młodzieży jest tym bardziej interesująca, kiedy zestawimy perspektywę roli młodzieży w społeczeństwie z teoretycznymi ustaleniami dotyczącymi uczestnictwa społecznego, bowiem jak pisze H. Świda-Ziemba,

zaangażowanie społeczne oznacza poczucie przynależności do społeczeństwa i akceptację własnego związku z grupami, np. narodową czy pokoleniową. Nie sprowadza się jednak tylko do świadomości "my”. Uznanie zaangażowania społecznego za zasadę życiowej orientacji ma miejsce wtedy, gdy świadomości "my" towarzyszy postulat działania dla dobra „nas wszystkich” i gotowość podjęcia współodpowiedzialności za realizację grupowych interesów, wartości, celów ${ }^{9}$.

W ten sposób młodzież poprzez współuczestnictwo i współdziałanie realizuje cele ogólnospołeczne i grupowe, będąc pełnoprawnym członkiem grup społecznych i społeczeństwa. Aktywność i uczestnictwo młodych ludzi rozumiana $\mathrm{w}$ ten właśnie sposób będzie zatem jednym z czynników dynamizujących społeczeństwo i wpływających na jego przeobrażenia. Uczestnictwo w życiu społecznym w literaturze przedmiotu definiowane i dookreślane jest za pomocą różnych kategorii i ujęć teoretycznych. T. HejnickaBezwińska nastawienie na aktywne współuczestnictwo i współdziałanie na

7 E. Jarosz, „Nic o was bez was". Obywatelstwo dzieci i młodzieży - rekomendacje globalne i rzeczywistość, [w:] Młodzież w dobie przemian społeczno-kulturowych, red. K. Segiet, Poznań 2015, s. 74-75.

${ }^{8}$ B. Kanclerz, Młodzież wychodzi na ulice czyli pozytywny wymiar wspótczesnej orientacji socjocentrycznej, [w:] Funkcjonowanie wspótczesnych młodych ludzi w zmieniającym się świecie, Warszawa 2012, s. 130.

${ }^{9}$ H. Świda- Ziemba, Młodzież a wartości, Warszawa 1979, s. 209. 
rzecz zmiany świata, a także miejsca w którym znajduje się jednostka, nazwała orientacją socjocentryczną ${ }^{10}$. Wskaźnikiem tej orientacji jest gotowość jednostki do zaangażowania się $\mathrm{w}$ realizację idei społecznie ważnych dla mniejszych lub większych grup społecznych ${ }^{11}$. W ramach tej kategorii może mieścić się wiele postaw, takich jak patriotyzm, postawa proreformatorska, postęp, sprawiedliwość społeczna, czynne uczestnictwo w wydarzeniach, aktywne życie $\mathrm{w}$ zbiorowości ${ }^{12}$. Aktywność społeczną na potrzeby swoich badań nad młodzieżą zdefiniowała także A. Cudowska, podkreślając, iż orientacja na uczestnictwo jest sposobem widzenia rzeczywistości w kategoriach systemów, grup społecznych, jak też indywidualnych jednostek, którym można pomagać. Orientacja na uczestnictwo łączy się z wrażliwością na potrzeby drugiego człowieka, ale także wyraża w chęci jednostki do zaangażowania się $\mathrm{w}$ realizację idei społecznie ważnych, które mogą przyczynić się do zmian w strukturze społecznej czy indywidualnych losach jednostek. Współcześnie, jak podkreśla autorka, może wyrażać się na przykład poprzez uczestnictwo w działalności społecznej, pozarządowej, czy wolontariacie ${ }^{13}$. Warto także dodać, że obecnie działalność społeczna z powodzeniem odbywa się zarówno $\mathrm{w}$ świecie realnym, jak i wirtualnym. Zatem, orientacja na uczestnictwo wyrażać się może $\mathrm{w}$ zupełnie nowych, niespotykanych we wcześniejszych pokoleniach formach. Przykłady akcji pomocowych organizowanych na portalach społecznościowych czy coraz bardziej popularny fundraising14 tylko potwierdzają tę tezę. Uczestnictwo "naszych czasów" nie musi bowiem oznaczać bycia w społeczeństwie w tradycyjnym - fizycznym rozumieniu, możemy angażować się bez kontaktu z drugim człowiekiem czy zbiorowością. Tak szeroko rozumiane uczestnictwo społeczne we wszystkich swych aspektach i wymiarach może realizować się zarówno w postaci niesformalizowanych działań określonych jednostek czy grup społecznych, jak i poprzez zinstytucjonalizowane oraz sformalizowane organizacje czy podmioty ${ }^{15}$. Należy podkreślić, iż orientacja na uczestnictwo, rozumiana między innymi jako gotowość do niesienia pomocy innym, sta-

${ }^{10}$ T. Hejnicka-Bezwińska, Orientacje życiowe młodzieży, Bydgoszcz 1991, s. 53.

11 Tamże.

12 Tamże.

13 A. Cudowska, Orientacje życiowe wspótczesnych studentów, Białystok 1997, s. 35.

14 Termin fundraising powstał z połączenia dwóch angielskich słów: fund - fundusze i raising - zbieranie. Oznacza zatem po prostu zbieranie funduszy i to głównie na cele charytatywne, publiczne. Fundraising to planowe, etyczne i skuteczne zbieranie pieniędzy, które mają służyć dobru wspólnemu. Każda złotówka podarowana na cel charytatywny trafia w całości do adresata; ze trony internetowej: http:/ / www.fundraising.org.pl/o-fundraisingu/

${ }_{15}$ R. Skrzypiec, Społeczna aktywność obywatelska a jakość życia mieszkańców. Przypadek gminy Lesznowola, [w:] Kapitat spoteczny. Partycypacja obywatelska. Rozwój lokalny, red. E. Psyk-Piotrowska, Łódź 2009, s. 152. 
nowi jeden z kluczowych składników kapitału społecznego ${ }^{16}$. Uczestnictwo społeczne, rozumiane jako strukturalny wymiar kapitału społecznego, jest w obszarze badań nad młodzieżą orientacją lokującą się wśród najważniejszych, bowiem rola kapitału społecznego w socjalizacji młodzieży jest niezwykle istotna ${ }^{17}$. Wskaźniki kapitału społecznego, między innymi takie, jak: członkostwo w sformalizowanych organizacjach społecznych, aktywne uczestnictwo, czy wsparcie organizacji społecznych oraz zaufanie do władz w teorii R.D. Putnama są kluczowe dla prawidłowego działania demokra$\mathrm{cji}^{18}$. Interesujące jest zatem uzyskanie odpowiedzi na pytanie: Jakie jest zaangażowanie i zaufanie społeczne młodzieży, która jest nie tylko odbiorcą, ale i kreatorem zachodzących zmian w wieloznacznej i ambiwalentnej rzeczywistości społeczno-kulturowej?

\section{Młodzież a uczestnictwo społeczne - analiza wyników badań}

Odwołując się do ustaleń teoretycznych, należy podkreślić, iż uczestnictwo młodych ludzi to wielość form aktywnego zaangażowania, nie tylko w świecie realnym, ale także coraz częściej w świecie wirtualnym. Orientacja na uczestnictwo to także kategoria, która wymaga rozróżnienia na sferę deklaratywną, jak i na realną działalność jednostek. Nie sposób więc w artykule zrekonstruować wszystkie formy uczestnictwa współczesnych młodych ludzi. Poniżej przybliżone zostaną zatem opinie i poglądy młodzieży dotyczące chęci pomocy innym ludziom oraz deklaracje badanych studentów odnośnie przynależności do instytucji czy organizacji zajmujących się pomocą innym. Orientacja na uczestnictwo była jedną z jedenastu orientacji życiowych (rozumianych jako całościowe podejście jednostki do rzeczywistości społecznej), wobec której opinie i poglądy zostały rozpoznane wśród badanych studentów ${ }^{19}$. Odwołując się do ustaleń teoretycznych ${ }^{20}$, badani

16 R.D. Putnam, Samotna gra w kręle. Upadek i odrodzenie wspólnot lokalnych w Stanach Zjednoczonych, Warszawa 2008, s. 196.

17 D. Hildebrandt-Wypych, Kapitat społeczny młodzieży jako podstawa socjalizacji politycznej oraz rozwoju spoteczeństwa obywatelskiego - sprawozdanie z badań niemieckich, Studia Edukacyjne, 2012, 22, s. 258.

18 Tamże, s. 263.

19 Typologia orientacji życiowych młodzieży akademickiej: orientacja na rodzinę, orientacja personalistyczna, orientacja rywalizacyjna, orientacja konsumpcyjna, orientacja na pracę, orientacja na karierę, orientacja na wycofanie, orientacja na perfekcjonizm, orientacja na uczestnictwo, orientacja na zdrowie, orientacja transcendentalna. Wyniki badań, które zostaną przedstawione poniżej są częścią rozprawy doktorskiej: Orientacje życiowe mtodzieży akademickiej, napisanej pod kierunkiem prof. dr hab. Agnieszki Cybal-Michalskiej i obronionej w maju 2015 roku na Uniwersytecie im. Adama Mickiewicza w Poznaniu. W badaniu wzięło udział 
studenci zostali poproszeni o odwołanie się do następujących twierdzeń, będących charakterystyką orientacji na uczestnictwo:

1. Chętnie podejmuję się zadań na rzecz innych ludzi, nawet jeżeli nie wiąże się to z żadnymi korzyściami materialnymi.

2. Należę do instytucji „,non-profit”, które zajmują się pomaganiem innym lub angażuję $\mathrm{w}$ prace na rzecz mojego otoczenia.

3. Jestem przekonana(y), że razem $\mathrm{z}$ innymi można zrealizować i wcielić $\mathrm{w}$ życie interesujące i pożyteczne idee.

4. Pomaganie innym sprawia mi satysfakcję i czuję się lepszym człowiekiem.

Analiza uzyskanych wyników ujawniła wewnętrzne zróżnicowanie w odpowiedziach badanych studentów. Młodzież w większości deklaruje, że pomaganie innym sprawia im satysfakcję $(93,7 \%)$ oraz wyraża przekonanie, że razem z innymi można zrealizować i wcielić w życie interesujące oraz pożyteczne idee (92,3\%), nawet jeżeli nie wiąże się to z żadnymi korzyściami $(82,2 \%)$. Warto jednak zauważyć, że poglądy i opinie wobec pomagania innym nie są tożsame $\mathrm{z}$ odpowiedziami badanych określającymi ich przynależność do instytucji i organizacji pozarządowych oraz z ich uczestnictwem w pracach na rzecz najbliższego środowiska. Niemalże całkowita akceptacja wobec pomagania innym oraz aprobata dla realizacji interesujących projektów nie przekłada się na uczestnictwo młodzieży w organizacjach. Tylko co trzeci badany student deklaruje, że należy do organizacji zajmującej się pomaganiem innym. Orientacja na uczestnictwo częściej charakteryzuje kobiety (średnia skali 3,04) (t-Studenta, p $<0,001)^{21}$ niż badanych mężczyzn. Jest orientacją dominującą wśród studentów pedagogiki (średnia skali 3,25; ANOVA, $\mathrm{p}<0,001)$, których przyszły zawód utożsamiany jest $\mathrm{z}$ pracą spo-

601 studentów z czterech uczelni poznańskich: Uniwersytetu im. Adama Mickiewicza w Poznaniu, Politechniki Poznańskiej, Uniwersytetu Ekonomicznego i Uniwersytetu Artystycznego. Po zastosowaniu celowego doboru próby, w badaniu uczestniczyli przedstawiciele sześciu dziedzin nauki (nauk humanistycznych, społecznych, prawnych, technicznych, ekonomicznych i sztuk plastycznych).

${ }^{20}$ Inspiracją włączenia do typologii orientacji na uczestnictwo był zaproponowany przez A. Cudowską typ orientacji społecznej, przy czym zaproponowana orientacja społeczna jest w swojej treści i zakresie szersza znaczeniowo o poczucie więzi ze środowiskiem sąsiedzkim, lokalnym, społecznym. Natomiast w treści orientacji na uczestnictwo skupiono się głównie na formach i wymiarach aktywności i uczestnictwa badanych.

${ }^{21} \mathrm{~W}$ prowadzonych badaniach zostały zastosowane określone procedury, które pozwoliły wyznaczyć, czy między dwiema zmiennymi istnieje związek, a także ustalić jaka jest siła tego związku oraz czy wyróżniony zróżnicował wartości badanej zmiennej. W analizie statystycznej brane pod uwagę były wyniki, dla których poziom istotności $(p) \leq 0,05$. Analiza istotności różnic ze względu na podstawowe zmienne społeczno-demograficzne została dokonana za pomocą testu t-Studenta $\mathrm{w}$ przypadku dwóch kategorii porównawczych oraz procedury jednoczynnikowej analizy wariancji (ANOVA) w przypadku wielu kategorii porównawczych. 
łeczną, pomaganiem innym oraz wcielaniem w życie interesujących i ważnych idei. Orientowanie się ",ku” uczestnictwu jest istotnie zróżnicowane ze względu na deklarowaną sytuację materialną badanych studentów. Osoby określające swój stan finansów jako bardzo dobry, w większym stopniu identyfikują się z orientacją na uczestnictwo (średnia skali 3,12; ANOVA, $\mathrm{p}=0,002)$. Wiek badanych studentów, ich wyniki w nauce, miejsce pochodzenia oraz plany edukacyjno-zawodowe, a także wykształcenie rodziców badanej młodzieży nie różnicuje orientacji na uczestnictwo badanych studentów. Przekonaniu, że pomaganie innym może sprawiać przyjemność sprzyja giętkość poznawcza, rozumiana jako otwartość na nowe doświadczenia i tolerancyjność $(\mathrm{P} ; \mathrm{r}=0,309 ; \mathrm{p}<0,001)$ oraz poczucie sprawstwa ( $\mathrm{P}$; $\mathrm{r}=0,313, \mathrm{p}<0,001)^{22}$. Istnieje także zależność pomiędzy przekonaniem o własnej wartości a orientacją na uczestnictwo (P; $r=0,362, p<0,001)$. Analiza wyników badań ujawniła odwrotnie proporcjonalną zależność pomiędzy orientacją na uczestnictwo a orientacją na wycofanie (P; $\mathrm{r}=-0,358$, $\mathrm{p}<0,001)$. Postawy będące przejawem bierności nie współwystępują zatem $\mathrm{z}$ nastawieniem na działanie i pomaganie innym. Uzyskane wyniki badań prowadzonych wśród studentów korespondują z badaniami prowadzonymi przez Stowarzyszenie Klon/Jawor ${ }^{23}$. Warto podkreślić, że według tych badań, prowadzonych w 2014 roku, tylko co czwarta badana młoda osoba (26\%) angażowała się $\mathrm{w}$ działalność organizacji pozarządowych. Jednak spośród wszystkich badanych grup wiekowych jest to najaktywniejsza część społeczeństwa. Z badania wynika bowiem, że tylko 18\% ogółu badanych angażuje się w wolontariat. Młodzi są zatem bardziej aktywni niż inne grupy wiekowe. Przywoływany raport zwraca także uwagę na zmienną, jaką jest sytuacja ekonomiczna badanych. Podobnie jak wśród badanych studentów, Raport Stowarzyszenia Klon/Jawor potwierdza, że częściej w uczestnictwo w organizacjach pozarządowych angażują się osoby lepiej zarabiają$\mathrm{ce}^{24}$. Inne badania, prowadzone na potrzeby Ministerstwa Pracy i Polityki Społecznej, analizują orientację na uczestnictwo w dwóch grupach wiekowych: 15-25 lat oraz 26-35 lat. Pierwsza grupa wiekowa znacznie częściej angażuje się w aktywność społeczną (22\% w badanej grupie), natomiast młodzi dorośli są znacznie mniej zaangażowani w wolontariat $(12 \% \mathrm{w}$ grupie wiekowej 26-35 lat). Jak podają autorzy badania, najwięcej wolontariuszy

$22 \mathrm{~W}$ celu określenia zależności pomiędzy zmiennymi zastosowano współczynnik r-Pearsona $(\mathrm{P})$, co pozwoliło uchwycić zależność (wprost proporcjonalną dla $\mathrm{r}>0$ ) oraz zależność odwrotnie proporcjonalną (dla wartości $\mathrm{r}<0$ ) pomiędzy zmiennymi.

23 Raport Stowarzyszenia Klon/Jawor ,Wolontariat, filantropia, 1\%", Warszawa 2014, dostęp ze strony internetowej http:/ / fakty.ngo.pl/wolontariat w dniu 20.12.2016.

24 Tamże. 
rekrutuje się spośród uczniów i studentów (29\%), i jest to znacznie większy odsetek niż wynosi średnia dla ogółu badanych $(16 \%)^{25}$. Można zatem zauważyć, że zarówno w sferze deklaratywnej, jak i w działaniach realnych młodzi ludzie są najbardziej aktywną grupą społeczną. Ciągle jednak zaangażowanie w aktywne uczestnictwo i współdziałanie pozostaje wyzwaniem edukacyjnym i socjalizacyjnym, bowiem odsetek młodych ludzi uczestniczących i aktywnie zaangażowanych w rozwój demokracji mógłby być z perspektywy rozwoju społeczeństwa - na znacznie wyższym poziomie.

\section{Uczestnictwo młodych a zaufanie społeczne}

Dopełnieniem rozważań nad uczestnictwem i zaangażowaniem społecznym współczesnych młodych ludzi jest zagadnienie związane z zaufaniem młodzieży do ludzi i instytucji. Jak podkreśla R. Putnam w swojej teorii kapitału społecznego, zaufanie społeczne związane jest bezpośrednio z wieloma formami obywatelskiego zaangażowania i uczestnictwa. Ludzie ufający innym współobywatelom częściej podejmują się pracy w charakterze wolontariuszy, więcej wpłacają na cele charytatywne, częściej włączają się w politykę i działanie organizacji lokalnych, wskazują większą gotowość do podjęcia obowiązków ławnika, częściej oddają krew jako honorowi krwiodawcy, są bardziej tolerancyjni dla poglądów mniejszości i przejawiają wiele innych cnót obywatelskich ${ }^{26}$. Eksperymenty psychologiczne dowiodły natomiast, że osoby wierzące w uczciwość innych, same rzadziej kłamią, oszukują i kradną oraz w większym stopniu respektują prawa innych. Autor teorii kapitału społecznego zwraca zatem uwagę, że uczciwość, uczestnictwo i zaangażowanie oraz zaufanie społeczne wzmacniają się wzajemnie ${ }^{27}$. Jak podkreśla natomiast A. Cybal-Michalska,

praktyczne zaangażowanie wymaga "przeskoku w wiarę" w powodzenie działań, którego źródłem jest zaufanie, związane z immanentną i pierwotną potrzebą bezpieczeństwa ontologicznego ${ }^{28}$.

Zatem, istotą zaangażowania młodzieży i jej funkcjonowania w życiu publicznym jest współwystępowanie orientacji na ufność wobec świata

25 Rządowy Program Aktywności Społecznej Młodzieży na lata 2015-2016 Aktywna Młodzież, Ministerstwo Pracy i Polityki Społecznej, Warszawa 2014, dostęp ze strony internetowej http://prom.info.pl/wp-content/uploads/2014/03/PASM_19.05.2014.pdf w dniu 20.12.2016.

26 R.D. Putnam, Samotna gra w kręgle, s. 230.

27 Tamże, s. 231.

${ }^{28}$ A. Cybal-Michalska, Tożsamość młodzieży, s. 74. 
i innych, którą T. Zysk zdefiniował jako przekonanie jednostki, iż może polegać na innych ludziach, na ich zobowiązaniach, czy wytworach ich pracy oraz że świat przede wszystkim społeczny otaczający człowieka jest zrozumiały i przyjazny, a więc można mu "zaufać” i być z nim w „Konstruktywnej" relacji. Jakość łączności podmiotu ze wspólnotą wyraża się również $\mathrm{w}$ przekonaniu, że instytucje społeczne, delegaci i reprezentanci społeczeństwa będą wykonywać to wszystko, co jest w interesie dobra ogólnego ${ }^{29}$. Odwołując się do powyższych ustaleń teoretycznych dotyczących ufności wobec innych i świata, badana młodzież akademicka została poproszona o odniesienie się do następujących stwierdzeń: można polegać na innych ludziach, otaczający świat jest przyjazny, instytucje polityczne działają w imię dobra społecznego, życiem społecznym nie rządzi korupcja i dbałość o własne interesy, ludzie z natury są dobrzy bez względu na religię, przekonania, czy poglądy polityczne ${ }^{30}$. Badana młodzież akademicka w większości wyrażała przekonanie, że można polegać na innych ludziach $(61,6 \%)$. Ponad połowa badanych uważa, że otaczający świat jest przyjazny $(53,1 \%)$. Jednak analiza wyników ujawnia szczególny brak zaufania do instytucji społecznopolitycznych. Studenci w znacznej większości podważają działanie w imię dobra społecznego instytucji politycznych $(75,1 \%)$, wyrażają także przekonanie, że w funkcjonowanie społeczne wpisana jest korupcja i dbałość o własne interesy $(82,5 \%)^{31}$. Negację wobec współczesnych elit politycznych wśród młodego pokolenia podkreślają także twórcy raportu Młodzi 2011, pisząc, iż co piąty młody uczący się Polak postrzega świat polityki jako: „,bagno", "bezsens”, „chaos", „cyrk”, miejsce walki o „stołki” i „stanowiska"32. Nagromadzony potencjał buntu młodzieży, wyrażony w negatywnym postrzeganiu polityki, nie musi jednak oznaczać w prostej konsekwencji bierności młodego pokolenia w życiu publicznym i społecznym. W tym przypadku jest raczej refleksją nad sferą publiczną, wobec której młodzi ludzie mają prawo formułować oceny, postulaty i opinie, a także oczekiwać, by zasady w niej panujące były przejrzyste. Kontestacja jest bowiem stylem typowym dla młodzieży usytuowanej korzystnie społecznie i edukacyjnie - zarówno dla licealistów, jak i studentów ${ }^{33}$. Tendencja ta potwierdza się także w nowszych wynikach badań: „Młodzi nie ufają politykom, aż 77\% z badanych uważa, że głównym celem przywódców partii poli-

${ }^{29}$ T. Zysk, Orientacja prorozwojowa, [w:] Orientacje społeczne jako element mentalności, s. 198.

30 Studenci swój pogląd mogli określić przez zaznaczenie na skali odpowiedzi: zdecydowanie tak (4), raczej tak (3), raczej nie (2), zdecydowanie nie (1).

${ }^{31}$ Procent skumulowany dla odpowiedzi zdecydowanie nie (1) i raczej nie (2).

32 M. Boni, K. Szafraniec (red.), Raport Młodzi 2011, s. 267.

${ }^{33}$ P. Bąk, Powody bierności politycznej młodzieży w jej własnych opiniach o sobie, cyt. za: tamże, s. 268. 
tycznych jest zdobycie władzy i czerpanie z niej osobistych korzyści. Jedynie $7 \%$ ma poczucie, że partie reprezentują ich interesy"34. Jak podkreśla się w analizie uzyskanych wyników badań, negatywne nastawienie młodzieży do polityków i polityki przekłada się na jej niską frekwencję wyborczą. Optymistyczne jest jednak to, iż wobec otoczenia społecznego niezwiązanego z polityką młodzież nie jest już tak krytyczna. Ludzie są z natury dobrzy, bez względu na religię, przekonania, czy poglądy - z taką opinią zgadza się $62,3 \%$ badanych studentów. Ponad połowa badanych uważa, że można polegać na innych ludziach $(61,6 \%)$ oraz że otaczający świat jest przyjazny (53,1\%). Można jednak z udzielanych odpowiedzi wywnioskować, że młodzież akademicką cechuje zasada ograniczonego zaufania ${ }^{35}$. Większą ufnością wobec innych i świata charakteryzują się badane kobiety (średnia 2,37; $\mathrm{t}$-Studenta, $\mathrm{p}=0,013$ ) oraz osoby dobrze oceniające swoją sytuację finansową (średnia skali 2,39; ANOVA, p =0,017). Pozytywniejszą opinię wobec świata otaczającego i innych ludzi mają pedagodzy (średnia 2,46) oraz prawnicy (2,41; ANOVA, p =0,035). Zastanawiające jest zatem, czy znaczenie ma tu zawód do jakiego przygotowują się studenci nauk społecznych i prawnych? Zarówno prawnicy, kuratorzy sądowi, nauczyciele i pedagodzy to osoby zaufania publicznego, do których należy wykonywanie zadań o szczególnym charakterze z punktu widzenia zadań publicznych i troski o realizację interesu publicznego ${ }^{36}$. Wydaje się zatem, że w tym można upatrywać większe zaufanie do świata społecznego studentów pedagogiki czy prawa. Studenci nauk technicznych rzadziej natomiast postrzegają świat jako zrozumiały i przyjazny (średnia 2,14), częściej negując działanie instytucji politycznych w imię dobra społecznego oraz wyrażając przekonanie, że ludzie przede wszystkim dbają o własne interesy. Zdecydowanymi przeciwnikami postrzegania świata jako zrozumiałego i przyjaznego są osoby, które nie uczestniczą w wydarzeniach kulturalnych ani nie odwiedzają instytucji kultury (średnia skali 1,74; ANOVA, p =0,010). Można zatem wnioskować, że pozostawanie w konstruktywnej relacji ze światem, któremu można zaufać nie jest oczywistą właściwością młodego pokolenia pozostającego tolerancyjnym wobec nowości i odmienności oraz charakteryzującego się ciekawością i giętkością poznawczą. Można jednak przypuszczać, że brak poczucia bezpieczeństwa oraz pejoratywne sądy o instytucjach życia społecznego

34 Rządowy Program Aktywności Społecznej Młodzieży na lata 2015-2016.

35 Odpowiedzi pozytywne zaznaczane były głównie dla skali „raczej tak”, co może przesądzać o niepewności w wydawanych sądach.

36 Zawody zaufania publicznego były przedmiotem prac Zespołu Analiz i Opracowań Tematycznych w Kancelarii Senatu RP, patrz: A. Krasnowolski, Zawody zaufania publicznego, zawody regulowane oraz wolne zawody. Geneza, funkcjonowanie i aktualne problemy, Warszawa 2013, s. 3. 
wynikają przede wszystkim z negatywnego postrzegania współczesnej polityki i tak zwanych "elit politycznych", a tego typu sądy o zewnętrznych kreatorach życia społecznego, mimo iż znaczące, nie będą przeszkodą w krystalizowaniu się u jednostek „umysłowości” nowoczesnej i prorozwojowej, zdolnej do uczestnictwa i zmiany w świecie.

\section{Zamiast zakończenia - uczestnictwo i zaufanie społeczne jako wyzwanie dla edukacji}

Przedstawione wyniki badań własnych oraz analiza danych zastanych pozwalają na optymistyczne wnioskowanie o kondycji współczesnej młodzieży. Jest to najbardziej aktywna grupa społeczna, nie tylko w sferze deklaratywnej, ale także $\mathrm{w}$ realnych działaniach, odzwierciedlających się w zaangażowaniu społecznym, filantropii, czy wolontariacie. Z drugiej zaś strony, zestawiając wyniki wszystkich badanych orientacji życiowych, orientacja na uczestnictwo nie jest dominującym kierunkiem działania młodego pokolenia. Młodzi przede wszystkim nastawieni są na indywidualny rozwój, własną karierę i rodzinę. Mimo że studenci i uczniowie stanowią najbardziej aktywne społecznie grupy, to dla pedagogów, wychowawców, nauczycieli oraz decydentów politycznych kształtowanie kompetencji społecznych pozostaje ciągle ważnym i aktualnym wyzwaniem edukacyjnym. Szczególnie niepokojący jest fakt, iż brak zaufania do instytucji życia publicznego czy polityków może blokować aktywność społeczną młodego pokolenia. Decydenci polityczni kształtując rekomendacje dla edukacji, zwracają uwagę na konieczność wspierania młodzieży, w szczególności $\mathrm{w}$ rozwijaniu własnych kompetencji społecznych poprzez kształtowanie postaw prospołecznych, zachęcanie do uczestnictwa w życiu publicznym, zachęcanie do aktywnego spędzania wolnego czasu, aktywności kulturalnej oraz fizycznej. W efekcie tych działań nastąpić ma nie tylko „zwiększenie świadomości wagi aktywności społecznej i wzrost kapitału społecznego, ale także poprawie ulegną szanse młodych ludzi na rynku pracy"37. Warto zatem zwrócić uwagę, że istotą działania w obszarze kształtowania aktywnego uczestnictwa młodych ma być nie tylko szkoła, ale także instytucje i podmioty zajmujące się edukacją nieformalną ${ }^{38}$. Odwołując się do uzyskanych wyników badań, można wnioskować, że wśród badanych studentów pedagogiki, którzy częściej niż inni studenci angażują się w działalność i uczest-

37 Rządowy Program Aktywności Społecznej Młodzieży na lata 2015-2016.

${ }^{38}$ L. Lannegrand-Willems, B. Barbot, Challenges of Adolescent Psychology in the European Identity Context, New Directions for Child and Adolescent Development, 2015, 147, s. 73. 
nictwo społeczne, efektywne dla kształtowania ich kompetencji społecznych są inicjatywy pozaformalne, takie jak: koła naukowe, samorząd studencki, wolontariat studencki, cykliczne imprezy o charakterze kulturalnym oraz wiele innych inicjatyw, które zwiększają szanse absolwentów na odnalezienie się na rynku pracy, ale także w niełatwej rzeczywistości społecznej. Szkoła - tu w znaczeniu młodzieży akademickiej - Uniwersytet powinny być miejscem warunkującym obszar społeczny, w którym się znajduje, jak i elementem społeczności lokalnej uwarunkowanej przez czynniki społeczne, tworząc tym samym przestrzeń dla rozwoju demokracji ${ }^{39}$.

\section{BIBLIOGRAFIA}

Boni M., Szafraniec K. (red.), Młodzi 2011, Kancelaria Prezesa Rady Ministrów, Warszawa 2011.

Cudowska A., Orientacje życiowe współczesnych studentów, Trans Humana, Białystok 1997.

Cybal-Michalska A., Tożsamość młodzieży w perspektywie globalnego świata. Studium socjopedagogiczne, Wydawnictwo Naukowe UAM, Poznań 2006.

Hejnicka-Bezwińska T., Orientacje życiowe młodzieży, Wyższa Szkoła Pedagogiczna, Bydgoszcz 1991.

Hildebrandt-Wypych D., Kapitat społeczny młodzieży jako podstawa socjalizacji politycznej oraz rozwoju spoteczeństwa obywatelskiego - sprawozdanie z badań niemieckich, Studia Edukacyjne, 2012, 22.

Jarosz E., "Nic o was bez was”. Obywatelstwo dzieci i młodzieży - rekomendacje globalne i rzeczywistość, [w:] Młodzież w dobie przemian społeczno-kulturowych, red. K. Segiet, Wydawnictwo Naukowe UAM, Poznań 2015.

Kanclerz B., Młodzież wychodzi na ulice czyli pozytywny wymiar wspótczesnej orientacji socjocentrycznej, [w:] Funkcjonowanie wspótczesnych młodych ludzi w zmieniającym się świecie, Wydawnictwo Difin, Warszawa 2012.

Kanclerz B., Orientacje życiowe młodzieży akademickiej, Wydawnictwo Naukowe UAM, Poznań 2015.

Krasnowolski A., Zawody zaufania publicznego, zawody regulowane oraz wolne zawody. Gene$z a$, funkcjonowanie i aktualne problemy, Kancelaria Senatu, Warszawa 2013.

Lannegrand-Willems L., Barbot B., Challenges of Adolescent Psychology in the European Identity Context, New Directions for Child and Adolescent Development, 147, Wiley Periodicals 2015.

Mannheim K., Problem młodzieży w nowoczesnym społeczeństwie, [w:] Młodziė̇ jako problem i jako wyzwanie ponowoczesności. Z prac Sekcji Socjologii Edukacji i Młodzieży PTS 2011 tom II, red. K. Szafraniec, Wydawnictwo Adam Marszałek, Torun 2011.

Melosik Z., Kultura popularna i tożsamość młodzieży. W niewoli władzy i wolności, Oficyna Wydawnicza Impuls, Kraków 2013.

39 Postulat ten wynika z optyki analizy edukacji z wykorzystaniem kapitału społecznego w perspektywie R.D. Putnama, zobacz: P. Mikiewicz, Kapitat społeczny i edukacja. Badanie porównawcze pomiędzy Polska i Islandia. Raport podsumowujący, Wrocław 2011, s. 29. 
Melosik Z., Kultura popularna, pedagogika i młodzież, [w:] Wychowawcze i społeczno-kulturowe kompetencje wspótczesnych nauczycieli, red. J. Pyżalski, theQ studio, Łódź 2015.

Mikiewicz P., Kapitat społeczny i edukacja. Badanie porównawcze pomiędzy Polską i Islandią. Raport podsumowujący, Dolnośląska Szkoła Wyższa, Wrocław 2011.

Peret-Drążewska P., Wspótczesna młodzież postrzegana z perspektywy rówieśników, Wydawnictwo Naukowe UAM, Poznań 2014.

Putnam R. D., Samotna gra w kręgle. Upadek i odrodzenie wspólnot lokalnych w Stanach Zjednoczonych, Wydawnictwo Akademickie i Profesjonalne, Warszawa 2008.

Raport Stowarzyszenia Klon/Jawor „Wolontariat, filantropia, 1\%”, Warszawa 2014, dostęp ze strony internetowej http:/ / fakty.ngo.pl/wolontariat z 20.12.2016.

Rządowy Program Aktywności Społecznej Młodzieży na lata 2015-2016 Aktywna Młodziė̇, Ministerstwo Pracy i Polityki Społecznej, Warszawa 2014, dostęp ze strony internetowej http://prom.info.pl/wp-content/uploads/2014/03/PASM_19.05.2014.pdf z 20.12.2016.

Skrzypiec R., Społeczna aktywność obywatelska a jakość życia mieszkańców. Przypadek gminy Lesznowola, [w:] Kapitat społeczny. Partycypacja obywatelska. Rozwój lokalny, red. E. Psyk-Piotrowska, Wydawnictwo Uniwersytetu Łódzkiego, Łódź 2009.

Świda-Ziemba H., Młodzież a wartości, Wydawnictwa Szkolne i Pedagogiczne, Warszawa 1979.

Świda-Ziemba H., Młodzi w nowym świecie, Wydawnictwo Literackie, Kraków 2005.

Zysk T., Orientacja prorozwojowa, [w:] Orientacje społeczne jako element mentalności, red. J. Reykowski, K. Skarżyńska, M. Ziółkowski, Wydawnictwo NAKOM, Poznań 1990. 